\title{
3 Research Square

\section{Implementation of a client-accessible and multidisciplinary youth health record in the Netherlands; a mixed-methods process evaluation}

Janine Benjamins ( $\square$ janine.benjamins@wur.nl )

Wageningen University \& Research

Jan-Gerrit Duinkerken

Stichting Jeugd Noord Veluwe

Gerlinde Jordaan

Wageningen University \& Research

Rianne Koster

Icare JGZ

Romay Canfijn

Wageningen University \& Research

Emely de Vet

Wageningen University \& Research

Annemien Haveman-Nies

Wageningen University \& Research

\section{Research Article}

Keywords: Electronic Health Records, Implementation, eHealth, Youth Care, Youth Social Services, Child Health Services, Preventive Child Health, Complex Intervention

Posted Date: October 18th, 2021

DOI: https://doi.org/10.21203/rs.3.rs-860481/v1

License: (a) (1) This work is licensed under a Creative Commons Attribution 4.0 International License. Read Full License 


\section{Abstract}

Background: Client-accessible patient records potentially contribute to patient-centered care by facilitating shared decision-making, enhancing interdisciplinary collaboration, and promoting patient's autonomy. To achieve this, three Dutch organizations providing 'care for youth' developed an electronic patient record (EPR-Youth). EPR-Youth supports working processes of all three organizations and is fully accessible for adolescents and for parents of children aged 0-16 years. Co-creation was chosen as implementation approach for this e-Health intervention that not only intervenes with technology (hardware) but also transforms working processes (orgware) and professional behavior (software).

Objective: to investigate the implementation process of EPR-Youth and to determine barriers and facilitators.

Methods: a mixed methods design was used. To guide the process evaluation, Pfadenhauers' Context and Implementation of Complex Interventions framework and Proctor's theoretic framework on implementation were used to define implementation outcomes and describe setting and context. Target groups were parents, adolescents, professionals using EPR-Youth, and all stakeholders in the implementation process.

Results: Barriers in the implementation process of EPR-Youth were the complexity of collaboration between stakeholders and the lack of clarity about leadership and project planning. Facilitating factors were clarifying the vision, setting deadlines, and a pioneering spirit.

Acceptability of the client-portal was high among all users. Adoption of the client-portal was highest among parents of children aged 0-3 years and among higher educated parents.

Professionals' doubts about user-friendliness and about the match with vision and working processes were partly due to lack of knowledge of all system functionalities.

Conclusion: The implementation of EPR-Youth, the first Dutch electronic patient record facilitating both preventive child health and youth care, was successful on 'hardware' level. To complete implementation on 'software' and 'orgware' level, client information needs attention, as well as training of professionals. Further research is needed to gain insight into barriers to access the client-portal. Although co-creation was an essential ingredient to reach project goals, situational leadership with more direction at the start and room for disruption is needed to guide this process.

\section{Background}

Worldwide, attention for patient-centered care is increasing [1, 2], because of its potential to enhance quality of care and reduce healthcare costs [3-5]. An important core value of patient-centered care is that the patient's wishes, needs, and expectations are equally important as the knowledge and expertise of the healthcare professionals [6-8]. Rendering both perspectives equally, health care professionals and 
patients come to shared decisions concerning the care process. Shared decision-making can be facilitated using a client-accessible electronic patient record (EPR), that contributes to transparency, promotes communication between patient and professional and enhances patient's involvement in their own care [9-11].

In the Netherlands, three core organizations in regional Centra for Youth and Family (CJG) collaboratively developed an electronic patient record for 'care for youth', 'EPR-Youth'. With the implementation of this client-accessible EPR, the regional CJG's aim for better interdisciplinary collaboration between CJGprofessionals, for increasing autonomy among parents and adolescents and, ultimately, improvement of perceived quality of care.

The implementation of EPR-Youth encompasses more than the mere introduction of a new technological tool (hardware) [12]. Use of EPR-Youth should also support a newly adopted shared way of thinking and future vision (software), facilitating a shift in professional behavior and attitude towards more clientcentered care. Furthermore, a change in organizational structures and rules (orgware) is necessary, when working processes of three organizations have to be merged virtually [12]. Therefore, the implementation of EPR-Youth can be considered a complex e-Health intervention. Based on system theory, stating that complex interventions will especially succeed if ideas and insights of all stakeholders are included, implementation of EPR-Youth was planned as co-creation between professionals, parents, adolescents, researchers, and IT-workers $[12,13]$.

The effect of EPR-Youth on clients' autonomy, interdisciplinary collaboration, and perceived quality of care will only be achieved after successful implementation, meaning that professionals and clients use the new system and use it in the way it was designed for. The effect is therefore dependent on the implementation process and implementation outcomes, like adoption, acceptability, appropriateness and fidelity [14]. Furthermore, the implementation processes interacts with the implementation setting and contextual factors [15]. Aiming for an evaluation framework that takes into account the complexity and context of the intervention, we followed the Context and Implementation of Complex Interventions (CICl) framework, which is developed specifically for this type of interventions [15].

The objective of this process evaluation is to investigate the implementation of EPR-Youth and to determine barriers and facilitators.

\section{Methods}

\section{Description:}

Reporting on the process evaluation, we followed the $\mathrm{CICl}$ framework (figure 1), describing intervention, setting and context, followed by implementation strategy and evaluation design [15].

Setting: 
EPR-Youth was developed and implemented in six municipalities of the Dutch region 'Noord Veluwe'. In 2015 , when national legislation changed, the municipalities ordered two organizations for preventive child healthcare and an organization for youth care to integrate their services, creating multidisciplinary teams in Centra for Youth and Family (CJG's). These teams provided preventive child healthcare to all children aged 0-18 years and youth care to children and families with psychosocial or behavioral problems. The reason for this integration was the need to transform 'care for youth' towards more clientcentered care [17]. The regional vision on client-centered care ties in with the United Nations Convention on the Rights of the Child statement that parents have the main responsibility for bringing up their children[18]. In line with parental responsibility, CJG-professionals support families to create their own care plans, matching with their personal situation and identity. Support from CJG-professionals collaboratively follows this 'family plan'. Part of the integration assignment was the development of a multidisciplinary and fully client-accessible EPR-Youth, facilitating the client-centered approach.

Intervention:

EPR-Youth was originally developed for preventive child health and had to be further developed to support working processes of youth care as well. Historic information from the existing health records of the three CJG-organizations was imported in the new EPR. All CJG-professionals, both from youth care and preventive child healthcare, reported in EPR-Youth. Through a client-portal, parents and adolescents that visit the CJG would have full access to their own record. They would be able read all reports, add information, ask questions, and manage appointments.

Context:

We considered the following aspects, more elaboratively described in Additional file 1, relevant to the development and implementation of EPR-Youth:

\section{Socio-cultural and geographical aspects}

the CJG-organizations differ both in structure and organizational culture. Both organizations for preventive child healthcare are part of a larger concern. When changes occur, one organization for preventive child healthcare aims for organizational uniformity over adaptation to regional developments, whereas the other organization prioritizes adaptation to regional development. Since 2015, CJGorganizations have increasingly based their services on a joint vision and a shared annual plan. However, they maintained their organization-specific working processes.

Socio-economic and political aspects: strict financial limits and annual settlement of budgets leave CJGorganizations little margin to maneuver. At the same time, municipalities feel a political urgency to facilitate this project adequately because EPR-Youth potentially contributes to the transformation process (see: 'Setting'). This process should also help to diminish shortages in youth care. Therefore, municipalities were willing to invest in a bottom-up co-creative implementation process for EPR-Youth.

\section{Ethical and legal aspects}

Page $4 / 26$ 
Due to the new and strict General Data Protection Regulations (GDPR) and since youth care and preventive child healthcare were providing their services under different laws, CJG-professionals were reluctant to share their reports with colleagues from other CJG-organizations. They also were hesitant to share real-time record contents with clients, especially when this content contained sensitive information. However, since July 2020, digitally sharing record content with clients is a legal obligation in the Netherlands [19].

Implementation theory, strategy, and agents:

Based on system theory, Leeuwis and Aarts emphasize that complex interventions will especially succeed if ideas and insights of all stakeholders are included $[12,13]$. Therefore, the implementation was designed as a co-creational process, starting with the development phase, aiming for support among all stakeholders. The intended changes, from development phase until long-term outcomes, are represented in a logic model of change (Figure 2), at an organizational, professional and client level.

A group of CJG-professionals, researchers, and IT builders, guided by a project leader, was appointed to develop and implement EPR-Youth together with parents and adolescents. The project group reported to a steering committee, consisting of the managers of the CJG-organizations, a medical specialist, and the project leader.

The project group was accountable for the process; the steering committee only intervened when needed. A consultative group of parents and adolescents advised about layout and content of the client-portal.

\section{Evaluation:}

\section{Process evaluation design}

For this process evaluation, we used a mixed methods design, obtaining data by using different methods, such as questionnaires, system data, focus group interviews, project documentation and observational reports. Data collection ran from May 2018 to November 2020 (see Table 1 for details). Analysis of context and setting was guided by the $\mathrm{CICl}$ framework, implementation factors were derived from the theoretical framework for implementation research by Proctor et al [14, 15].

\section{Target groups and recruitment}

The research group consisted of different target groups: parents, adolescents, and professionals that were using EPR-Youth; members of the steering committee, guiding the development and implementation; professionals co-creating EPR-Youth with IT-developers. Table 1 describes which target group was approached in which part of the study. One year after introduction of EPR-Youth, all clients visiting a CJG received the clients' questionnaire. From the respondents that indicated willingness to participate in a focus group, two groups of clients were selected by purposive sampling. Criteria were that all six municipalities should be represented, both parents and adolescents, both male and female. The clients also represented different educational levels and were making use of different CJG-services. 
The professionals' questionnaire was distributed among 92 CJG-professionals from all three organizations, representing all available disciplines. For the focus group interviews with professional users and with the project group, purposive sampling was used to ensure that participants represented all disciplines and organizations involved, both sexes and different levels of working experience. In the focus group interview with the steering committee, all members of the steering committee were included except one person, who was interviewed separately.

\section{Measurements}

\section{System assessment}

To evaluate whether EPR-Youth was delivered as intended, a system assessment was performed by the first author (JB) and members of the project group, comparing EPR-Youths' delivered functionalities with project documentation and with the project contract.

Implementation process

The first author (JB) participated in all steering committee meetings, all project group meetings and all consultative group meetings with parents and adolescents. All meetings were audio-recorded. Project documentation was used for triangulation. The focus groups with project group members and with the steering groups were used to further define barriers and facilitators in the implementation process.

Implementation outcomes

Acceptability, adoption, appropriateness, and fidelity were chosen as implementation outcomes.

Acceptability was assessed among both professionals and clients, with questionnaires based on the Technology Acceptance Model [21] (Additional file 2). The professionals' questionnaire contained nine questions from the System Usability Scale about 'perceived ease-of-use' (Cronbach's alpha $=0,92$ ) and four questions from a questionnaire by Davis et al. about 'perceived usefulness' (Cronbach's alpha $=0,84$ ), complemented with one open-ended question [21,22]. The clients' questionnaire was embedded into an already existing patient satisfaction survey, that was administered to alls clients who visited a CJG. The questionnaire contained three questions about 'ease-of-use', two about 'adoption', one about 'desirability of a client accessible EPR' and one open-ended question. In both questionnaires, respondents were asked to rate their answers on a 5-point Likert scale, ranging from 'totally agree' to 'totally disagree'. To match high scores with a positive opinion, all scores were reversed, except for four questions in the professionals' questionnaire, that were reversely worded (figure 3). Results were presented in a descriptive way.

Adoption, meaning the extent to which clients logged on to the client-portal, was assessed from system data. The number of clients that logged on were counted and presented per month and as a total. To calculate number of log-ons per client, multiple log-ons on the same day were counted as one. 
The focus groups with clients and professionals were conducted to assess appropriateness, meaning 'fit with working processes', and fidelity, meaning 'being used as intended'. 
Table 1

Overview of chosen process indicators and implementation outcomes, corresponding data-collection method, examination period, and target group for the process evaluation of EPR-Youth.

\begin{tabular}{|c|c|c|c|}
\hline $\begin{array}{l}\text { Indicator/outcome: } \\
\text { description }\end{array}$ & Data & Period & $\begin{array}{l}\text { Target } \\
\text { group/actors }\end{array}$ \\
\hline $\begin{array}{l}\text { System assessment: } \\
\text { Has EPR-Youth been } \\
\text { developed as intended } \\
\text { and in accordance with } \\
\text { the contract? }\end{array}$ & $\begin{array}{l}\text { - Contract between IT-developer } \\
\text { and CJG-organizations } \\
\text { - Document 'system assessment' } \\
\text { - Project documentation }\end{array}$ & $\begin{array}{l}\text { Sept '19 } \\
\text { (immediately } \\
\text { after } \\
\text { implementation) }\end{array}$ & $\begin{array}{l}\text { - Not } \\
\text { specified }\end{array}$ \\
\hline $\begin{array}{l}\text { Implementation process } \\
\text { and context: } \\
\text { Analysis of legal/ethical, } \\
\text { socio-cultural, } \\
\text { geographical political } \\
\text { and socio-economic } \\
\text { contextual aspects that } \\
\text { were affecting the } \\
\text { implementation process. }\end{array}$ & $\begin{array}{l}\text { - Verbatim transcripts project group } \\
\text { meetings ( } 34 \times 3 \text { hours), steering } \\
\text { committee meetings ( } 17 \times 1,5 \text { hours) } \\
\text { and consultative group meetings } \\
\text { ( } 7 \times 2 \text { hours) } \\
\text { - Semi-structured focus group } \\
\text { interviews with steering committee } \\
\text { ( } n=6) \text { and project group }(n=8) \\
\text { - Project documentation }\end{array}$ & $\begin{array}{l}\text { May '18-Sept '19 } \\
\text { June '20 } \\
\text { Jan '16-Sept '19 }\end{array}$ & $\begin{array}{l}\text { - Steering } \\
\text { committee, } \\
\text { project group, } \\
\text { consultative } \\
\text { group } \\
\text { parents \& } \\
\text { adolescents } \\
\text { - Steering } \\
\text { committee } \\
\text { and project } \\
\text { group }\end{array}$ \\
\hline $\begin{array}{l}\text { Acceptability: To what } \\
\text { extent were users, both } \\
\text { professionals and clients, } \\
\text { satisfied with the } \\
\text { intervention? [14] }\end{array}$ & $\begin{array}{l}\text { - Professionals' questionnaire } \\
(\mathrm{n}=66) \text { : experienced ease-of-use } \\
\text { and experienced usefulness } \\
\text { - Questionnaires parents ( } \mathrm{n}=914) \\
\text { and adolescents }(\mathrm{n}=89) \text { : } \\
\text { desirability client-access, actual } \\
\text { access, and experienced ease-of- } \\
\text { use. } \\
\text { - Semi-structured focus group } \\
\text { interviews with professionals } \\
(\mathrm{n}=12), \text { parents }(\mathrm{n}=8) \text { and } \\
\text { adolescents }(\mathrm{n}=4) \text { : how do } \\
\text { professionals and clients } \\
\text { experience the use of EPR-Youth } \\
\text { and the client-portal? }\end{array}$ & $\begin{array}{l}\text { Feb '20 } \\
\text { Sept-Nov '20 } \\
\text { Nov' } 20\end{array}$ & $\begin{array}{l}\cdot \text { CJG- } \\
\text { professionals } \\
\text { - Parents and } \\
\text { adolescents } \\
\text { that visit a } \\
\text { CJG } \\
\text { - } \\
\text { Professionals } \\
\text { and clients }\end{array}$ \\
\hline $\begin{array}{l}\text { Adoption: To what extent } \\
\text { were clients using the } \\
\text { client-portal? [14] }\end{array}$ & $\begin{array}{l}\text { - System data: monthly and total } \\
\text { number of clients that logged on to } \\
\text { the portal } \\
\text { - Questionnaires parents }(\mathrm{n}=914) \\
\text { and adolescents }(\mathrm{n}=89) \text { : } \\
\text { percentage of respondents that } \\
\text { logged on to the client-portal }\end{array}$ & $\begin{array}{l}\text { Sept '19-Dec '20 } \\
\text { Sept-Nov '20 }\end{array}$ & $\begin{array}{l}\cdot \text { Clients } \\
\text { - Parents and } \\
\text { adolescents } \\
\text { that visit a } \\
\text { CJG }\end{array}$ \\
\hline
\end{tabular}




\begin{tabular}{|c|c|c|c|}
\hline $\begin{array}{l}\text { Indicator/outcome: } \\
\text { description }\end{array}$ & Data & Period & $\begin{array}{l}\text { Target } \\
\text { group/actors }\end{array}$ \\
\hline $\begin{array}{l}\text { Appropriateness: To what } \\
\text { extent does EPR-Youth } \\
\text { match with working } \\
\text { processes of } \\
\text { professionals? [14] }\end{array}$ & $\begin{array}{l}\text { - Meeting reports of project group } \\
\text { and steering committee } \\
\text { - Semi-structured focus group } \\
\text { interviews with professionals } \\
(\mathrm{n}=12) \text { : Do professionals feel a } \\
\text { match between EPR-Youth and } \\
\text { their working processes? }\end{array}$ & $\begin{array}{l}\text { May '18-Sept '19 } \\
\text { Nov '20 }\end{array}$ & $\begin{array}{l}\text { - Steering } \\
\text { committee } \\
\text { and project } \\
\text { group } \\
\text { - CJG- } \\
\text { professionals }\end{array}$ \\
\hline $\begin{array}{l}\text { Fidelity: To what extent } \\
\text { are professionals and } \\
\text { clients using EPR-Youth } \\
\text { and the client-portal as } \\
\text { intended, in accordance } \\
\text { with the vision on } \\
\text { transformation? [14] }\end{array}$ & $\begin{array}{l}\text { - Semi-structured focus group } \\
\text { interviews with steering committee } \\
(\mathrm{n}=6) \text { and project group }(\mathrm{n}=8) \\
\\
\text { - Semi-structured focus group } \\
\text { interviews with professionals } \\
(\mathrm{n}=12) \text {, parents }(\mathrm{n}=8) \text { and } \\
\text { adolescents }(\mathrm{n}=4) \text { : Do participants } \\
\text { experience that EPR-Youth is } \\
\text { supporting professionals to work in } \\
\text { accordance with the vision on } \\
\text { transformation? }\end{array}$ & $\begin{array}{l}\text { June '20 } \\
\text { Nov '20 }\end{array}$ & $\begin{array}{l}\text { - Steering } \\
\text { committee } \\
\text { and project } \\
\text { group } \\
\text { - } \\
\text { Professionals } \\
\text { and clients }\end{array}$ \\
\hline
\end{tabular}

\section{Data-analysis}

Quantitative data were analyzed using IBM SPSS Statistics 25 and Microsoft Excel. Demographic data of clients that logged on to the client-portal were compared with those of the source population, testing for differences with Chi-square tests. Client-portal access percentages were tested for difference according to sex, age or native country with Chi-square or Fisher's exact tests. Client user experience scores were tested for differences according to educational level and native country. Kruskal-Wallis was used as omnibus test and the Mann Whitney-U as post-hoc test. For professionals' user experiences, two dimensions were defined: perceived ease-of-use and perceived usefulness. For each dimension, an average score was calculated. These scores were tested for differences according to age and organization, using one way ANOVA as omnibus test, and Tukey HSD as post-hoc test.

Qualitative data were analyzed using ATLAS.ti, version 8 and 9 for Mac $(22,23)$. All project meetings, focus group interviews and individual interviews were audio-recorded and transcribed verbatim. Coding and analyzing was an iterative process by four researchers (RK, GJ, RC, JB). In the first round, working in pairs, they coded all text in a mix of inductive and deductive coding; in a second round, themes were identified through selective coding, resulting in a code tree (Additional file 3). Subsequently, memos and characteristic text fragments for each theme were compiled into a report and discussed by the researchers. Finally, interpretation of the themes was discussed (JB, AH, JD, GJ)

\section{Results}


System assessment.

In September 2019, a prototype of EPR-Youth was launched that was not finished yet. All CJGprofessionals could write their reports in the system. The client-portal, however, contained only basic functionalities: clients could manage appointments and ask questions. They had access to vaccination status and growth data. Full access to visit notes and to a viewlog, showing which professionals had accessed their record, followed in 2020. Automatic portal access was limited to parents of preschool children. Adolescents and parents of children aged 4 years and older were given access manually upon their request.

In June 2020, most members of the steering committee and project group said that EPR-Youth was performing well for now. However, the system was still under development: 'Proud that we have something working, which is not yet finished, but is developing in the intended direction'. [109:153] 'that we have actually delivered something that our professionals can work with' [109:154].

Implementation process:

Based on qualitative analysis of focus group interviews and project meetings, we defined barriers and facilitators in the implementation process.

\section{Barriers:}

Complexity of co-creative process: The project proceeded slower than expected, partly due to underestimation of the complexity of a co-creative process of change: 'We are actually going to use one EPR-system with three organizations. So we're going to merge virtually.... think we underestimated the complexity behind it....'[31:63]. Underlying to this complexity were differences between organizations. Whereas the members of the steering committee shared one vision about care for youth, this vision appeared not to be embraced yet throughout all three organizations. A steering committee member said: 'You share a vision.... but it also has to fit the organization you're in. And then, along the way.....,you discover how incredibly difficult that can be'[109:10] In the project group, someone said: '.... that we have had a great deal of trouble pretending to be one organization, while we are not at all. And that it does not come to the surface, .... that we are not working on one vision now' [107:28] In the project group, the differences in vision and working method induced recurring substantive and legal discussions, creating interpersonal tensions: 'At the end, I saw the eyes turning like: there they are again'. [107:6]

Leadership: The project group felt the project was lacking a plan with clear division of responsibilities: 'It was very ad hoc...I missed a plan of action...clarity about everyone's role'. [107:3] Although the project group was expected to show shared ownership of the process, they did not at first experience ownership, nor did the project leader require ownership from them: '...since the project leader was constantly saying "we have to ask the steering committee about that" ...'[107:152] Maintaining balance between selforganizing as a project group and receiving directions from the steering committee was a recurring theme. Whereas the project leader called for directing professionals' attitude and behavior, the steering 
committee held back, trusting the change process to continue organically: 'setting up the vision is an ongoing process....this is a change of culture' [82:24]

The steering committee acknowledged that, as a result 'the project group ... might felt thrown in at the deep end sometimes'[109:24]. They could have intervened earlier, especially in recurring discussions about vision: 'The steering committee ... including myself... assumed too easily that everyone knew the ultimate objective.'[108:9]

\section{Facilitators:}

Structuring the process: The project group appreciated that, at a certain point, clear deadlines were set: 'That deadline had to be met at all costs. Then, we were able to make rigorous decisions.' [107:13] The steering committee agreed with that: 'Yes, that deadline was helpful. As far as I'm concerned, we should have set many more deadlines.' [108:96] At the same point, the project group was divided in smaller groups, working on specific tasks. This was also perceived as helpful and contributed to the sense of ownership: 'This is what people had suggested for a long time: one group working on the content, and another working on other issues, like the newsletter, the user's manual and things like that' [107:13].

Clarifying the vision: To the project group, a clear explanation of the vision beforehand would have been helpful: 'I would have liked to dwell more on the vision, really share it with each other...'. [107:7] Simultaneously, they valued clarifying the vision through their discussions. After the process of clarification, they felt that decision-making became easier: '...somehow, we needed that process to be able to take decisions..... once everyone clearly understood the 'why', decisions were taken quickly'. [107:11] The steering committee said the process of jointly clarifying the vision had also reduced resistance: 'the resistance among professionals is, eh, much less than it was.'[109:156]

Pioneering spirit: Everybody was aware of the pioneering character of this project, realizing that there was no earlier example that could be copied: 'That made it more tolerable, because we were just taking up this challenge together that no one had tackled before.'[107:38] and '.... at a birthday party, it's nice to be able to tell...this project is unique in the Netherlands.' [107:15]. This awareness created a feeling of pride, both in the steering committee and in the project group: 'I'm also proud... we've had some pretty tough discussions, some people have even left... but we are still getting along very well'. [107:14]

Implementation Outcomes

Acceptability:

The steering committee considered the initial implementation a success. In their focus group interview, one member said: 'We noticed few interruptions where it comes to... user adoption... In terms of... user acceptance, the process went quite smoothly' [109:63]. An application manager said: 'We have had relatively few start-up problems...... d do get questions, but nothing like "what a miserable system" or "we can't work with this".' [107:149] 
From the 914 parents and 89 adolescents that completed the clients' questionnaire, The client questionnaire 511 parents and 15 adolescents reported they had logged on to the client-portal and responded on the user experience questions (figure 3). Clients were predominantly positive about easy access, comprehensibility, and clear overview. No difference in scores were found according to educational level or native country. In the focus groups, clients reported that the client-portal was easy to use. However, adolescents considered the obligatory two-factor authentication time-consuming: 'You have to enter the website and you need to verify in, like, four steps..., so you have to take your time,.....to check things' [5:146].

Professionals differed in their opinion about ease-of-use. One participant in a focus group said 'It's easy to fill in. (EPR-Youth)' [112:19], whereas someone else said: 'it's a nuisance'. [112:45]. The professionals' questionnaire was completed by 66 of the $92(72 \%)$ invited CJG professionals (figure 3). A statistically significant difference for ease-of-use was found between different organizations, and between age groups. Professionals delivering preventive child healthcare to pre-school children scored significantly more positive in this domain $(M=3,36, S D=1.0)$ than youth care professionals $(M=2.6, S D=0.86)$, as determined by Tukey HSD post-hoc test $(p<0.001)$. Professionals aged 60 years and older scored significantly more positive in this domain $(M=3.8, S D=0.72)$ than professionals between 40 and 50 years of age $(M=2.4, S D=0.88)$, as determined by Tukey HSD post-hoc test $(p=0.02)$. Professionals reported both in focus groups and in the questionnaire that they particularly appreciated new time-saving functionalities, like automatically generating referrals or indication statements. However, many professionals appeared not to be familiar with all possibilities of EPR-Youth.

Answers were given on a 5-point Likerts scale, ranging from 'absolutely' (1) to 'not at all' (5) for clients, and ranging from 'totally agree (1)' to 'totally disagree' (5) for professionals. Scores were reversed for all questions, except the ones marked with an asterisk, resulting in low scores representing a negative opinion and high scores representing a positive opinion. In the clients' questionnaire, Q2-4 was answered only by parents and adolescents that had logged in on the client-portal.

Adoption:

In de North Veluwe region live approximately 38.000 children, aged 0 to 18 year, and 52.800 parents. As CJG-clients, they all have access to the client-portal. In the period September 2019 until December 2020, 5174 clients logged in to the portal. In the first five months, the monthly number of portal users slowly increased, then stabilized around 1200 portal users monthly. Table 2 shows that most portal users were women (87.1\%) and most users were aged between 30 and 44 years $(76.6 \%)$. Compared to the average local population, few portal users were of non-Dutch nativity. The average number of logons per person was 3.7 (SD 4.1) in 15 months, ranging from 1 to 47 logons. No differences were found in logon frequency, according to sex, age and native country. 
Table 2

Mean number of logons to client-portal, in relation to demographic characteristics of portal users; distribution of portal user's demographic characteristics is compared with general population of the North Veluwe region, aged 15 to 65.

Source: Central Bureau for Statistics Netherlands.

\begin{tabular}{|c|c|c|c|c|}
\hline & & $\begin{array}{l}\text { Mean logons } \\
\text { per user (SD) }\end{array}$ & $\begin{array}{l}\text { Number of users } \\
\text { (percentage) }\end{array}$ & $\begin{array}{l}\text { Inhabitants } \\
\text { North Veluwe } \\
\text { (percentage) }\end{array}$ \\
\hline \multicolumn{2}{|l|}{ TOTAL } & 3.68 (SD 4.1) & 5174 & \\
\hline \multirow[t]{3}{*}{$\operatorname{Sex}^{\mathrm{a}}$} & Male & 3.72 (SD 4,4) & $65912.7 \%)$ & $50.5 \%$ \\
\hline & Female & 3.67 (SD 4.0) & 4509 (87.1\%) & $49.5 \%$ \\
\hline & Unknown & & $6(0.1 \%)$ & \\
\hline \multirow[t]{3}{*}{$\operatorname{Age}^{\mathrm{b}}$} & $15-29$ years & 3.57 (SD 4,0) & 1107 (21.4\%) & $28.4 \%$ \\
\hline & $30-44$ years & 3.69 (SD 4.3) & 3964 (76.6\%) & $27.6 \%$ \\
\hline & $45-64$ years & 3.87 (SD 4.0) & $102(2.0 \%)$ & $44.0 \%$ \\
\hline \multirow{7}{*}{$\begin{array}{l}\text { Native } \\
\text { countryc }\end{array}$} & Netherlands & 3.68 (SD 4.1) & 4895 (94.6\%) & $92.4 \%$ \\
\hline & Surinam & 2.00 (SD 1.4) & $5(0.1 \%)$ & $0.2 \%$ \\
\hline & Netherlands Antilles & 4.40 (SD 3.4) & $5(0.1 \%)$ & $0.1 \%$ \\
\hline & Turkey & 3.75 (SD 3.5) & $28(0.5 \%)$ & $1.0 \%$ \\
\hline & Morocco & 4.13 (SD 5.3) & $15(0.3 \%)$ & $0.5 \%$ \\
\hline & $\begin{array}{l}\text { Europe, North America, } \\
\text { Oceania, Indonesia, Japan }\end{array}$ & 3.55 (SD 3.7) & $105(2.0 \%)$ & $2.8 \%$ \\
\hline & Other countries & 3.68 (SD 3.9) & $121(2.3 \%)$ & $3.1 \%$ \\
\hline \multicolumn{5}{|c|}{ a Significantly different from North Veluwe population (Chi²-test (1) 2945.942, 2-sided p<0.001) } \\
\hline \multicolumn{5}{|c|}{ b Significantly different from North Veluwe population (Chi²-test (2) 6671.353, 2-sided $p<0.001$ ) } \\
\hline
\end{tabular}

The clients' questionnaire showed that logon percentages among parents differed, according to educational level, family composition and children's age (Table 3). These differences did not appear among adolescents. Parents of children aged 0-3 years, reported most often that they had logged on to the client-portal. As reasons to logon to the portal, clients mentioned: checking or managing appointments $(72.4 \%)$, reading what was discussed (54.3\%), asking a question (16.7\%) and adding or changing information (2.5\%). In the client focus groups, most participants reported they had not been aware of the existence of the client-portal until they were invited to complete the clients' questionnaire. 
Table 3

Comparison of login percentages among respondents of the client questionnaire, according to sociodemographic characteristics. Percentages are given between brackets.

Parents

Logged in

$\mathrm{N}=490$

$(53,8)$
Total Statistic $\mathrm{N}=911$

Adolescents

2-

p-

value

Logged in Total Statistic 2-

$\mathrm{N}=14 \quad \mathrm{~N}=87 \quad$ sided

$(16,1)$

\section{Educational}

level

\begin{tabular}{|c|c|c|c|c|c|c|c|c|}
\hline Low & $32(50,8)$ & 63 & \multirow{3}{*}{$\begin{array}{l}\mathrm{c} 2=(2) \\
9.285\end{array}$} & 0.01 & $6(15,0)$ & 40 & \multirow{3}{*}{$\begin{array}{l}\mathrm{c} 2=(1) \\
0.671\end{array}$} & 0.413 \\
\hline Middle & $207(50)$ & 414 & & & \multicolumn{2}{|l|}{ NA } & & \\
\hline High & $230(60,5)$ & 380 & & & $7(22,6)$ & 31 & & \\
\hline Missing & 21 & 54 & & & 1 & 16 & & \\
\hline
\end{tabular}

\section{Family composition}

\begin{tabular}{|c|c|c|c|c|c|c|c|}
\hline $\begin{array}{l}\text { 2-Parent } \\
\text { family }\end{array}$ & $452(58,9)$ & 768 & $\begin{array}{l}\mathrm{c} 2=(1) \\
49.523\end{array}$ & $<0.001$ & $5(16,1)$ & 31 & $\begin{array}{l}\text { Fisher's } \\
\text { exact }\end{array}$ \\
\hline $\begin{array}{l}\text { Other } \\
\text { situation }\end{array}$ & $16(18,8)$ & 85 & & & $7(15,9)$ & 44 & \\
\hline Missing & 22 & 58 & & & 2 & 12 & \\
\hline
\end{tabular}

$\begin{array}{lllllllll}\text { Netherlands } & 431(54,5) & 791 & \begin{array}{l}c 2=(1) \\ 0.447\end{array} & 0.504 & 12(17,4) & 69 & \begin{array}{l}\text { Fisher's } \\ \text { exact }\end{array} & 0.581 \\ \begin{array}{lllll}\text { Other } \\ \text { country }\end{array} & 15(48,4) & 31 & & & 0(0,0) & 6 & & \end{array}$

$\begin{array}{lllll}\text { Missing } & 44 & 89 & 2 & 12\end{array}$

\section{Age children}

$\begin{array}{lllll}\text { Children 0-3 } & 401(77,0) & 521 & \mathrm{c} 2=(1) & <0.001 \\ \mathrm{y} & & & 264.065\end{array}$

Children 4- $\quad 67(20,2) \quad 332$

$18 \mathrm{y}$

Missing

22 58

Appropriateness 
In 2019, a prototype was launched that was considered 'good enough': the system supported the most important working processes of CJG professionals. In the focus groups, youth care workers, as opposed to preventive child health professionals, reported that EPR-Youth not fully matched their working processes. As a result, youth care workers sometimes felt as if they were 'visiting' someone else's system: 'As a youth care professional, it feels as if I am allowed to report in a preventive child health system [111:34]'. Administrative assistants on the other hand, felt that EPR-Youth supported their working processes better than before. However, one assistant reported that she missed a crucial functionality to plan ahead. 'During the pandemic, I had to deliver numbers concerning delay in our regular work. Honestly, I don't know how...' [111:43] A few professionals used to report information about parents that was not to be read by the child, for instance in case of a divorce: 'I don't think a 12-year-old should have to read that.'[112:242] In EPR-Youth, however, adolescents aged 12 and older have full access to their own EPR. Information in an adolescents' EPR can be shielded from parents, but not from the adolescents themselves. For professionals who frequently must deal with difficult divorce situations, this felt as an obstacle in their working processes.

\section{Fidelity}

To test fidelity, we discussed with professionals in the focus groups whether the system was being used and implemented as intended. Professionals reported that EPR-Youth facilitated interdisciplinary collaboration: 'If you know that other colleagues are involved as well, you can read what they have written'[112:21] and: '... when a child starts at school, for example, that you don't have to transfer the record to the other preventive healthcare organization anymore.' [111:2] Moreover, professionals noticed that the ability to read and to plan appointments enhanced parent's involvement. 'Yes, managing appointments is nice, for parents as well. Parents can also have a look in the portal and become more involved'. [112:16]. One member of the steering committee considered transparency for clients the most important achievement: 'We are breaking .....(an unwritten law), that it is no longer possible, at least, to report things...that clients are unaware of.' [108:93].

On the other hand, some functionalities were not utilized by all CJG-organizations: the possibility to manage appointments, for example, was offered by only one CJG-organization. Furthermore, professionals appeared to lack knowledge of some functionalities and how to use them as intended: "I have a lot of colleagues who still write their indication statements in MS Word.' [112:171] and 'Actually, everything you just said is new to me'. [112:32] Ultimately, some professionals struggled to make EPRYouth work for them, concordant with the regional vision, and requested additional training. 'Of course, this is about doing your job in line with our vision, and about the moments of tension that arise from that.'[112:507]

\section{Discussion}

The aim of this comprehensive process evaluation was to investigate the implementation of EPR-Youth and to determine barriers and facilitators. 
Complexity of collaboration between stakeholders and a lack of clarity about leadership and project planning were experienced as the most important barriers during implementation. These barriers can be interpreted as a side-effect of the choice to develop and implement EPR-Youth in a step-by-step cocreational process with relevant stakeholders $[12,23,24]$. Co-creation is a non-linear process, which is very suitable for innovation [25]. Key to co-creation is that participants go through a time-consuming and often frustrating process that starts with expressing opinions and acknowledging divergent perceptions, followed by the challenging of assumptions and working through disagreements. [26-28]. In the project, professionals from three different organizational cultures had acknowledge and challenge each other's views, needs and wishes, to reach a turning point where they could begin to search for inclusive solutions [28]. Ultimately, going through this process leads to a deepening sense of connection within the group [27-30].

Opposed to co-creational processes, most organizations mainly focus on productive processes that can be organized efficiently and in a linear way [25]. This was the case in one organization for preventive child healthcare, having a strictly limited budget and being part of a larger concern that aimed for uniformity. As a result, there was little room to deviate from the intended use of staff hours, limiting the needed space to think through the renewal process and leading to frustration among professionals about repeating discussions that caused delay.

The disruptive character of co-creational processes requires situational leadership that is adapting guidance of the participants in each phase of the process [31, 32]. At the start, the group is in search for direction and objectives. Therefore, leadership needs to be directive, setting clear goals [26, 32]. The discussion and polarization phase requires a coaching leadership style, keeping the group focused on the vision, stimulating the search for joint solutions and creating space and time for renewal processes [33]. Fry et al. describe this as "spiritual leadership" [34]. In the last phase of co-creation, responsibility for shared goals will develop within the group, requiring more facilitative instead of directive leadership [26, 32]. the steering committee chose a facilitative leadership style from the start, immediately expecting shared ownership of goals in the project group. Eventually, shared interpretations were formulated, and the feeling of solidarity and commitment within the project group increased. However, situational leadership, adapting to the changing needs and managing the participants' expectations, could have diminished the turbulence of the project.

A sense of pioneering, meaning the awareness of joint commitment to the creation of something new, was considered a facilitating factor. Former research shows that such commitment is an important ingredient of successful innovation processes. Senge et al. say in this regard: "virtually every significant change initiative that we have seen starts with a genuine partnership among a small number of deeply committed individuals" [35]. In the context of change management, Clemmer and Warrick use the term 'change champions': individuals in various segments of the organization who make indispensable contributions to initiating, facilitating and implementing change $[36,37]$. Participating in the development 
and implementation of EPR-Youth, the professionals in the project group can be seen as 'change champions', initiating and supporting the intended change among professionals and clients using EPRYouth.

\section{Implementation Outcomes}

Client-portal adoption was highest among high-educated clients, while educational level appeared of no influence on experienced ease-of-use. The relation between client-portal adoption and educational matches findings from earlier research, showing lower portal use than average among low-educated clients [38-41]. When portal use is lower among so-called disadvantaged groups, the introduction of technological tools like EPR-Youth, potentially enhances socio-economic health differences [42]. This is called 'digital divide', and could be caused by lower access to information technology, limited skills and knowledge to use information technology or a mismatch with clients' live experiences [43]. However, previous research shows that disadvantaged groups experience more benefits from the use of a clientportal than average [44-47]. These findings emphasize the importance of easy-accessible and easy-touse client-portals. In our study, it is hopeful to find that educational level does not influence experienced ease-of-use. However, to gain insight in barriers and facilitators for client-portal access, further research is needed.

Client-portal adoption was also high among parents of pre-school children. This could be explained by the fact that they were already familiar with a limited client-portal in the previously used system. Moreover, through the old client-portal, they had been individually informed about the new client-portal, whereas adolescents and parents of older children were informed mainly through local press, social media, and flyers. An individual letter by mail was not sent because the COVID-19 pandemic outbreak caused a sudden shift in priorities. Another possible explanation for the faster client-portal adoption by parents of pre-school children could be that they visit the CJG regularly for preventive health checks and advice. In the first year after birth, ten regular visits are planned, followed by yearly follow-up until 4 years. During the school period, regular check-ups are limited to once every few years. Finally, adapting and making appointments was only possible for parents with pre-school children. Parents of older children and youth care clients could check their appointment date, but not change it. Therefore, parents of preschool children were more inclined to access their client-portal.

Professionals reported very differently on experienced ease-of-use and usefulness of EPR-Youth. They also differed in opinion about appropriateness and fidelity of the system. In an innovation process, this is not unexpected, because every change process has early adopters and so-called 'laggards' [48]. The lack of knowledge of all system functionalities and the struggle of some professionals to translate the vision into working processes in EPR-Youth could be explained by such natural differences in adoption speed. However, professionals also experienced some mismatches between working processes and EPR-Youth, cherishing old habits and refusing to adopt new working methods that were supported by EPR-Youth. These issues go deeper and need to be understood from the nature of complex interventions, generating change in technology (hardware), working processes and institutional change (orgware), and 
professional attitude and behavior (software) [13]. The co-creation of such interventions requires interaction over time between the technological, institutional, and social components and their context, in a continuous cycle of feedback and learning $[13,49]$. Implementing EPR-Youth, the changes in professional attitude and adoption of newer working processed were delayed because the planned action-learning program was put on hold due to the COVID-19 epidemic, while the technological development continued as planned.

From this perspective, 'having developed a system professionals can work with' can be considered a success on 'hardware' level, although the 'hardware' challenge to lower thresholds for clients to access the client-portal is still open. To complete the implementation on 'orgware' and 'software' level, it is important to continue the cycle of learning and feedback [33]. Part of the solution on "software" level could be the professionals' training in knowledge of functionalities and in the ability to translate vision in to working processes in EPR-Youth. Finally, to keep the change process going, a structural change in 'orgware' towards situational leadership, knowing when to be directive and when to guide with room for renewal, is vital.

\section{Strengths and limitations}

The combination of both quantitative and qualitative data from different sources, e.g. system data, project documentation, observation reports, questionnaires and focus group interviews was a strength in this process evaluation. This allowed us to view the results from all>variety relevant perspectives.

The professionals' questionnaire was held 5 months after initial implementation. Considering answers to the open-ended questions, insufficient familiarity with EPR-Youths' functionalities could be partly responsible for the relatively low scores. Moreover, not all CJG-professionals had been included: only colleagues who had been working in het CJG since the start of development of EPR-Youth had received the questionnaire, leaving out the new colleagues. In focus group interviews, however, new colleagues reported positively about ease-of-use of EPR-Youth. Therefore, not including them in the questionnaire might have caused a bias, underestimating the experienced ease-of-use of EPR-Youth.

JB actively participating in meetings of project group, steering committee and client consultative group can be considered both a strength and a limitation [50]. From an empirical positivist perspective, interference with the process is unwelcome, since generalizability of outcomes will diminish and the researchers' objectivity could decline [51]. In action research, however, knowledge is produced through interaction with the process and its participants [52]. Through continuous reflection on the process, delivering feedback to the steering committee and project group, JB contributed to the achievement of project goals $[51,52]$. The following measures were taken, aiming for intersubjectivity : focus group interviews by an independent reviewer; co-analyzing with researchers not involved in the implementation process; member check on both interview transcripts and all quotes in this paper [53].

The earlier mentioned COVID-19 pandemic also influenced the data collection. Professionals' questionnaires were completed just before the pandemic, whereas client questionnaires that were 
planned one month later had to be postponed 6 months. Therefore, the implementation period had been shorter for professionals. That might have caused a lower perception of ease-of-use, due to lack of familiarity with all functionalities, whereas clients reported more positively because they had had more time to adjust.

\section{Conclusion}

The 'hardware' implementation of EPR-Youth, the first Dutch EPR that facilitates both preventive child health and youth care, was successful. However, more time and effort are needed to complete implementation on 'software' and 'orgware' level. To inform clients about the existence of EPR-Youth, more communication is needed, especially towards groups with lower adoption rate. Further research is needed to gain insight into barriers for client-portal access. To enhance acceptability among professionals, and a better understanding of the match between EPR-Youth, working processes, and organizational vision on care for youth, we recommend additional training.

Although co-creation was an essential ingredient to reach project goals, situational leadership with more direction at the start and room for disruption is needed to guide the process.

\section{Abbreviations}

$\mathrm{ClCl}$

context and implementation of complex interventions

CJG

Centra for Youth and Family

EPR

Electronic Patient Record

EPR-Youth

Electronic Patient Record for Care for Youth

\section{Declarations}

\section{Ethical approval and Consent to participate:}

All methods were carried out in accordance with relevant guidelines and regulations, complying with the Netherlands Code of Conduct for Scientific Practice. On these grounds, the research protocol was approved by the Social Sciences Ethics Committee of Wageningen University.

All respondents to questionnaires and participants in focus groups received an invitation beforehand with information about the study. Respondents to the questionnaire gave a written consent: after a summary of the study information, the questionnaire started with a consent question. Participants in the focus groups gave an explicit verbal consent at the beginning of the focus group interview. Each interview was 
recorded and transcribed verbatim, including the verbal consent. Both procedures were approved by the ethics committee.

If participants were 12-16 years old, consent to participate was collected from their parents/guardians as well. Parents and adolescents both received information about the study beforehand. Parents gave their consent verbally when they visited the CJG with their child. The adolescent questionnaire contained an extra question about parental consent, to be answered by the adolescent. Adolescents aged 12-16 years that participated in the focusgroups receive a parental consent form beforehand to be completed by their legal guardian. These forms were collected at the start of the focusgroup interview.

\section{Consent to publish:}

Not applicable

\section{Availability of data and materials:}

The datasets generated during and/or analysed during the current study are deposited in the DANS EASY repository, DOI: 10.17026/dans-znd-cgwm, https://doi.org/10.17026/dans-znd-cgwm, and will be available after an embargo period of two years. Until then, the datasets can be retrieved upon request from the corresponding author.

\section{Competing interests:}

The authors declare that they have no competing interests.

\section{Funding:}

This study has been funded by ZonMw, project nr 736300019. Before granting the funds, ZonMw has had the project proposal reviewed. ZonMw has played no role in the design of the study and collection, analysis, and interpretation of data and in writing the manuscript.

\section{Author contibution:}

$J B, J D, E V$ and $A H$ have written the design of the study

Data were collected by JB, RK and GJ

Data analysis and interpretation: JB, JD, RC, RK, GJ, AH

The article was drafted by JB. 
All authors have critically revised the article.

All authors have read and approved the final manuscript.

\section{Acknowledgements:}

Not applicable

\section{References}

1. Medicine lo: Crossing the quality chasm: a new health care system for the 21 st century. Washington, DC; 2001.

2. Gerties M E-LS, Daley J, Delbanco TL, eds.: Through the patients' eyes: understanding and promoting patient-centred care. San Francisco, CA: Jossey-Bass; 1993.

3. WHO SDaS: WHO global strategy on people-centred and integrated health services, interim report. 2015.

4. Bertakis KD, Azari R: Patient-centered care is associated with decreased health care utilization. The Journal of the American Board of Family Medicine 2011, 24:229-239.

5. Epstein RM FP, Shields CG, Meldrum SC, Miller KN, Campbell TL, Fiscella K.: Patient-centered communication and diagnostic testing. Ann Fam Med 2005, Sep-0ct:415-421.

6. Podlog LW, Brown WJ: Self-determination Theory: A Framework for Enhancing Patient-centered Care. The Journal for Nurse Practitioners 2016, 12:e359-e362.

7. Scholl I, Zill JM, Härter M, Dirmaier J: An Integrative Model of Patient-Centeredness - A Systematic Review and Concept Analysis. PLOS ONE 2014, 9:e107828.

8. Mead N, Bower P: Patient-centred consultations and outcomes in primary care: a review of the literature. Patient Education and Counseling 2002, 48:51-61.

9. de Lusignan S, Mold F, Sheikh A, Majeed A, Wyatt JC, Quinn T, Cavill M, Gronlund TA, Franco C, Chauhan $U$, et al: Patients' online access to their electronic health records and linked online services: a systematic interpretative review. BMJ Open 2014, 4:e006021.

10. Vermeir P, Degroote S, Vandijck D, Van Tiggelen H, Peleman R, Verhaeghe R, Mariman A, Vogelaers D: The patient perspective on the effects of medical record accessibility: a systematic review. Acta Clin Belg 2017, 72:186-194.

11. Benjamins J HA, Gunnink M, Goudkuil A, de Vet E: How the Use of a Patient-Accessible Health Record Contributes to Patient-Centered Care: Scoping Review. J Med Internet Res 2021, 23(1):e17655.

12. Leeuwis $\mathrm{C}$, Aarts $\mathrm{N}$ : Rethinking Communication in Innovation Processes: Creating Space for Change in Complex Systems. The Journal of Agricultural Education and Extension 2011, 17:21-36.

13. Kilelu CW, Klerkx L, Leeuwis C: Unravelling the role of innovation platforms in supporting co-evolution of innovation: Contributions and tensions in a smallholder dairy development programme. 
Agricultural Systems 2013, 118:65-77.

14. Proctor E, Silmere H, Raghavan R, Hovmand P, Aarons G, Bunger A, Griffey R, Hensley M: Outcomes for Implementation Research: Conceptual Distinctions, Measurement Challenges, and Research Agenda. Administration and Policy in Mental Health and Mental Health Services Research 2011, 38:65-76.

15. Pfadenhauer L, Rohwer A, Burns J, Booth A: Guidance for the assessment of context and implementation in health technology assessment and systematic reviews of complex interventions: the context and implementation of complex interventions (CICl) framework. 2016.

16. Pfadenhauer L, Rohwer A, Burns J, Booth A: Guidance for the assessment of context and implementation in health technology assessment and systematic reviews of complex interventions: the context and implementation of complex interventions (CICl) framework. 2017.

17. Transformatieplan Samenwerking Noord Veluwe 2018-2021

[https://vng.nl/sites/default/files/noord_veluwe.pdf]

18. United Nations Convention on the Rights of the Child, art 18.1. (Nations U ed.; 1989.

19. Dutch Ministry of Public Health WeS: Wet aanvullende bepalingen verwerking persoonsgegevens in de zorg. 2018.

20. Foundation WK: WK Kellogg Foundation logic model development guide. WK Kellogg Foundation; 2004.

21. Davis FD: Perceived Usefulness, Perceived Ease of Use, and User Acceptance of Information Technology. MIS Quarterly 1989, 13:319-340.

22. Brooke J: SUS: a "quick and dirty'usability. Usability evaluation in industry 1996:189.

23. Pretty JN, Guijt I, Thompson J, Scoones I: Participatory learning and action-A trainers guide.

24. Thomas T, Mefalopulos P: Participatory communication: A practical guide. The World Bank; 2009.

25. Bateson G: Mind and nature: A necessary unity. New York: Bantam Books; 1979.

26. Leeuwis C: Communication for rural innovation: rethinking agricultural extension. John Wiley \& Sons; 2013.

27. Mandl C, Hauser M, Mandl $\mathrm{H}$ : What is a Co-creative Meeting? In The Co-creative Meeting. Springer; 2013: 7-13.

28. Kaner S: Facilitator's guide to participatory decision-making. John Wiley \& Sons; 2014.

29. Tuckman BW: Developmental sequence in small groups. Psychological bulletin 1965, 63:384.

30. Tuckman BW, Jensen MAC: Stages of small-group development revisited. Group \& Organization Studies 1977, 2:419-427.

31. Rill B: Resonant co-creation as an approach to strategic innovation. Journal of Organizational Change Management 2016, 29:1135-1152.

32. Hersey P, Blanchard KH, Natemeyer WE: Situational Leadership, Perception, and the Impact of Power. Group \& Organization Studies 1979, 4:418-428. 
33. Rotmans J: Maatschappelijke innovatie; tussen droom en werkelijkheid staat complexiteit [Oration]. Rotterdam: Erasmus Universiteit; 2005.

34. Fry L, Hannah S, Noel M, Walumbwa FO: Impact of spiritual leadership on unit performance. In.; 2011

35. Senge P, Kleiner A, Roberts C, Ross R, Roth G, Smith B, Guman EC: The dance of change: The challenges to sustaining momentum in learning organizations. Performance Improvement 1999, 38:55-58.

36. Clemmer J: Harnessing the energy of change champions. Retrieved November 2004, 20:2004.

37. Warrick D: Developing organization change champions. OD practitioner 2009, 41:14-19.

38. Aljabri D, Dumitrascu A, Burton MC, White L, Khan M, Xirasagar S, Horner R, Naessens J: Patient portal adoption and use by hospitalized cancer patients: a retrospective study of its impact on adverse events, utilization, and patient satisfaction. BMC Med Inform Decis Mak 2018, 18:70.

39. Yamin CK, Emani S, Williams DH, Lipsitz SR, Karson AS, Wald JS, Bates DW: The digital divide in adoption and use of a personal health record. Arch Intern Med 2011, 171:568-574.

40. Myrah Wouters IS, Britt van Lettow, Judith de Jong,, Judith Sinnige AB, Roland Friele, Lies van Gennip: E-Health monitor, E-health in verschillende snelheden. (Nivel N ed. Den Haag en Utrecht: Nictiz en Nivel; 2018.

41. Lester M, Boateng S, Studeny J, Coustasse A: Personal Health Records: Beneficial or Burdensome for Patients and Healthcare Providers? Perspectives in health information management 2016, 13.

42. Viswanath K, Kreuter MW: Health disparities, communication inequalities, and eHealth. Am J Prev Med 2007, 32:S131-133.

43. Latulippe K, Hamel C, Giroux D: Social health inequalities and eHealth: a literature review with qualitative synthesis of theoretical and empirical studies. Journal of medical Internet research 2017, 19:e136.

44. Bell SK, Mejilla R, Anselmo M, Darer JD, Elmore JG, Leveille S, Ngo L, Ralston JD, Delbanco T, Walker $\mathrm{J}$ : When doctors share visit notes with patients: a study of patient and doctor perceptions of documentation errors, safety opportunities and the patient-doctor relationship. BMJ Qual Saf 2017, 26:262-270.

45. Gerard M, Chimowitz H, Fossa A, Bourgeois F, Fernandez L, Bell SK: The Importance of Visit Notes on Patient Portals for Engaging Less Educated or Nonwhite Patients: Survey Study. Journal of medical Internet research 2018, 20.

46. Gerard M, Fossa A, Folcarelli PH, Walker J, Bell SK: What patients value about reading visit notes: a qualitative inquiry of patient experiences with their health information. Journal of medical Internet research 2017, 19.

47. Jackson SL, Mejilla R, Darer JD, Oster NV, Ralston JD, Leveille SG, Walker J, Delbanco T, Elmore JG: Patients who share transparent visit notes with others: Characteristics, risks, and benefits. Journal of Medical Internet Research 2014, 16.

48. Rogers EM: Diffusion of innovations. 5th edition edn. New York: Free Press; 2003. 
49. Hekkert MP, Negro SO: Functions of innovation systems as a framework to understand sustainable technological change: Empirical evidence for earlier claims. Technological forecasting and social change 2009, 76:584-594.

50. Gold RL: Roles in sociological field observations. Soc F1957, 36:217.

51. Reason P, Torbert W: The action turn: Toward a transformational social science. Concepts and transformation 2001, 6:1-37.

52. Bradbury-Huang $\mathrm{H}$ : What is good action research?:Why the resurgent interest? Action Research 2010, 8:93-109.

53. Brydon-Miller M, Greenwood D, Maguire P: Why Action Research? Action Research 2003, 1:9-28.

\section{Figures}

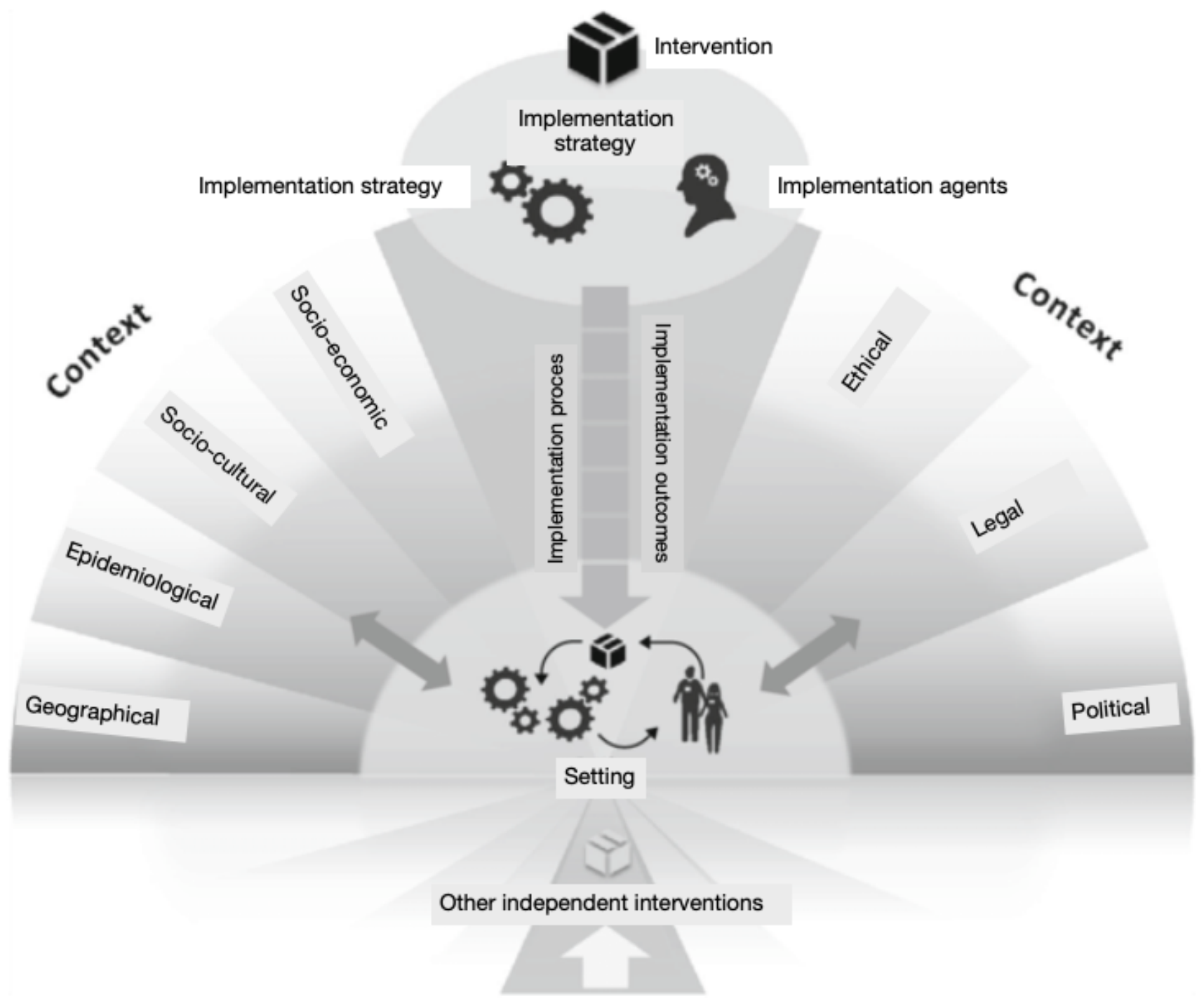

Figure 1

Framework for Context and Implementation of Complex Interventions (CICl), Pfadenhauer 2017[16] 
Contextual factors: collaboration between 3 different CJG-organizations; culture change (transformation) towards patient-centredness; ethical/legal dilemmas of transparent health record; health literacy/educational level parents and youths

\begin{tabular}{|c|c|c|c|c|c|c|c|}
\hline$\downarrow$ & $\downarrow$ & $\downarrow$ & $\downarrow$ & $\downarrow$ & $\downarrow$ & $\downarrow$ & $\downarrow$ \\
\hline Input & Activities dev. phase & Output dev. phase & Activities impl. phase & Implement. output & Med. term Outcomes & Long term Outcomes & Overall Aim \\
\hline $\begin{array}{l}\text { Steering group } \\
\text { Project group: } \\
\text {-professionals } \\
\text {-IT-developers } \\
\text { Research team } \\
\text { Consultative } \\
\text { group: }\end{array}$ & $\begin{array}{l}\text { Organizations: } \\
\text {-monitor \& } \\
\text { consolidate } \\
\text { 'transformation' } \\
\text { process } \\
\text {-check working } \\
\text { processes } \\
\text {-facilitate match } \\
\text { between IT, } \\
\text { working process \& } \\
\text { vision }\end{array}$ & 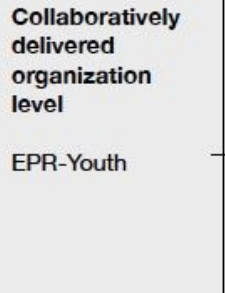 & $\begin{array}{l}\text { Organizations: } \\
\text {-monitor \& } \\
\text { consolidate } \\
\text { 'transformation' } \\
\text { process } \\
\text {-adapt working } \\
\text { processes } \\
\text {-facilitate 'fit' } \\
\text { possible between } \\
\text { IT, work \& vision }\end{array}$ & $\begin{array}{l}\text { Organizations: } \\
\text { EPR \& Portal are: } \\
\text {-acceptable } \\
\text {-adopted } \\
\text {-appropriate (match } \\
\text { with working } \\
\text { processes) } \\
\text {-and show fidelity } \\
\text { (match with vision) }\end{array}$ & $\begin{array}{l}\text { Organizations: } \\
\text { no specific } \\
\text { organisational } \\
\text { outcomes } \\
\text { defined }\end{array}$ & \multirow{3}{*}{$\begin{array}{l}\text { Experienced } \\
\text { Better Quality of } \\
\text { Care for Youth } \\
\text { Client Reported } \\
\text { Experience } \\
\text { Measurements } \\
\text { based on CJG } \\
\text { Quality Values: } \\
\text {-child-centered } \\
\text {-client 'in the lead' } \\
\text {-involvement } \\
\text { family } \\
\text {-plans fit with } \\
\text { needs and } \\
\text { expectations } \\
\text {-mutual trust } \\
\text { between } \\
\text { professionals and } \\
\text { clients }\end{array}$} & \multirow[t]{3}{*}{$\begin{array}{l}\text { HAPPY } \\
\text { HEALTHY } \\
\text { CHILDREN } \\
\text { \& } \\
\text { YOUTHS }\end{array}$} \\
\hline \multirow[t]{2}{*}{$\begin{array}{l}\text { Financial resources } \\
\text { Time investment } \\
\text { Input from } \\
\text { 'transformation } \\
\text { vision documents' }\end{array}$} & $\begin{array}{l}\text { Professionals: } \\
\text {-develop EPR } \\
\text { with developers } \\
\text {-develop } \\
\text { communication } \\
\text { materials } \\
\text {-develop training } \\
\text { for professionals } \\
\text {-develop privacy } \\
\text { docs }\end{array}$ & $\begin{array}{l}\begin{array}{l}\text { Collaboratively } \\
\text { delivered } \\
\text { professional level }\end{array} \\
\text {-Training plan for } \\
\text { professionals } \\
\text {-Privacy docs }\end{array}$ & $\begin{array}{l}\text { Professionals: } \\
\text {-technical training } \\
\text {-'action learning', } \\
\text { focused on match } \\
\text { IT, working } \\
\text { process and } \\
\text { vision } \\
\text {-learn to report } \\
\text { objectively }\end{array}$ & $\begin{array}{l}\text { Professionals: } \\
\text {-know how to use } \\
\text { EPR } \\
\text {-know how to use } \\
\text { according to vision } \\
\text { (meaningful use) } \\
\text { - write objective } \\
\text { reports } \\
\text { - share info with } \\
\text { colleagues }\end{array}$ & $\begin{array}{l}\text { Professionals: } \\
\text {-information } \\
\text {-involve client in } \\
\text { care } \\
\text {-involve relevant } \\
\text { others from network } \\
\text {-communication } \\
\text { client } \& \text { colleague } \\
\text {-collaboration with } \\
\text { client } \& \text { colleagues } \\
\text {-empowerment } \\
\text { client }\end{array}$ & & \\
\hline & $\begin{array}{l}\text { Parents/youths: } \\
\text {-develop } \\
\text { Tethered Client } \\
\text { Portal with } \\
\text { developers }\end{array}$ & $\begin{array}{l}\begin{array}{l}\text { Collaboratively } \\
\text { delivered client } \\
\text { level }\end{array} \\
\text {-Client portal } \\
\text {-Communication } \\
\text { materials }\end{array}$ & $\begin{array}{l}\text { Parents/youths: } \\
\text {-being informed } \\
\text { about client } \\
\text { portal } \\
\text {-process/vision }\end{array}$ & $\begin{array}{l}\text { Parents/youths: } \\
\text {-know about client } \\
\text { portal } \\
\text {-know how to use } \\
\text {-able to read/ } \\
\text { understand } \\
\text { - read, add info } \\
\text { - decide who has } \\
\text { access to EPR }\end{array}$ & $\begin{array}{l}\text { Parents/youths: } \\
\text {-informed } \\
\text {-involved in care } \\
\text {-network involved } \\
\text {-communicating } \\
\text { with professionals } \\
\text {-collaboration with } \\
\text { professionals } \\
\text {-autonomous } \\
\text { clients }\end{array}$ & & \\
\hline
\end{tabular}

\section{Figure 2}

logic model of change for EPR-Youth, based on the WK Kellogg Foundation logic model development guide[20] 


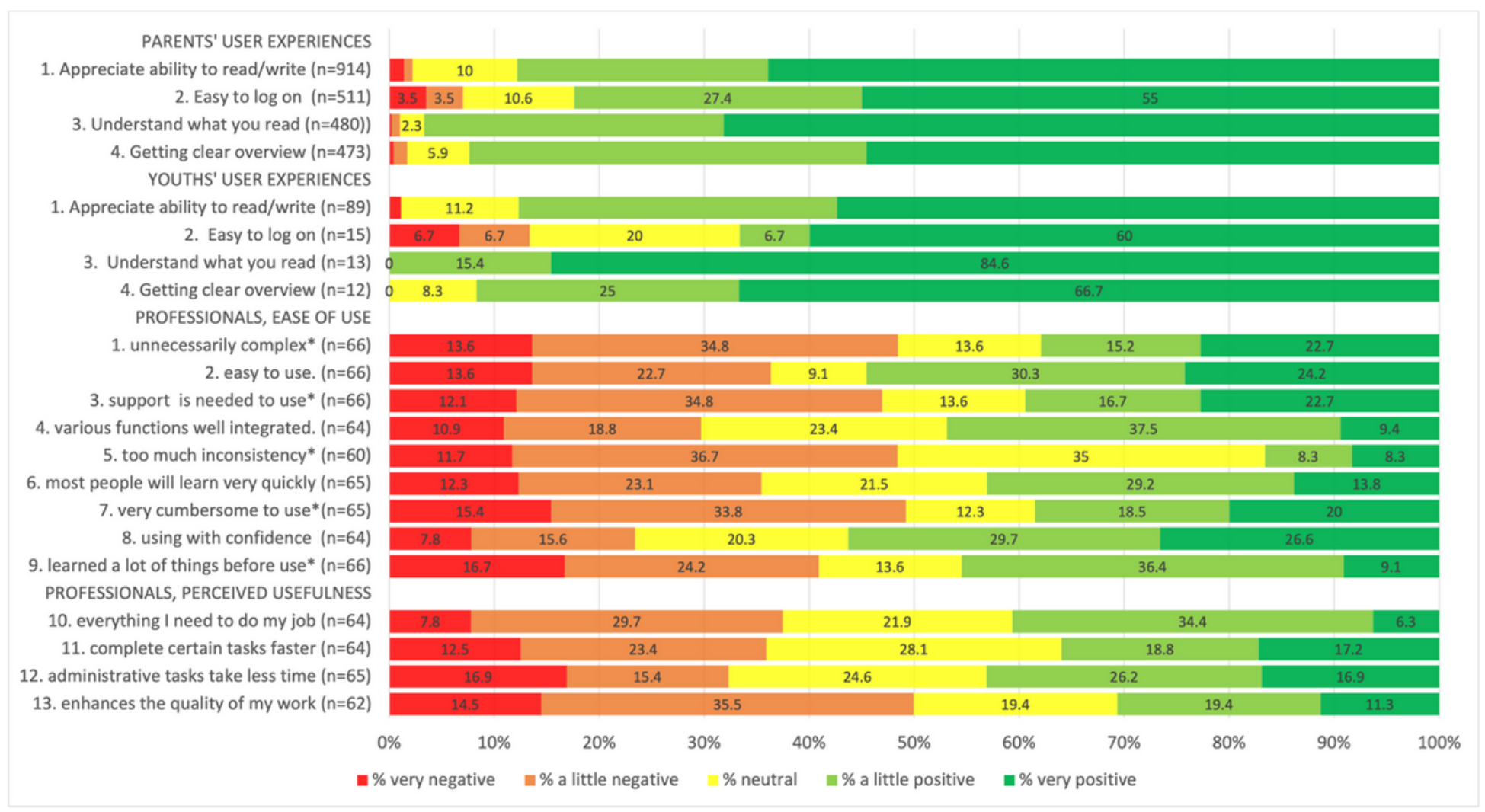

\section{Figure 3}

Clients' and professionals' users experiences with EPR-Youth. Answers were given on a 5-point Likerts scale, ranging from 'absolutely' (1) to 'not at all' (5) for clients, and ranging from 'totally agree (1)' to 'totally disagree' (5) for professionals. Scores were reversed for all questions, except the ones marked with an asterisk, resulting in low scores representing a negative opinion and high scores representing a positive opinion. In the clients' questionnaire, Q2-4 was answered only by parents and adolescents that had logged in on the client-portal.

\section{Supplementary Files}

This is a list of supplementary files associated with this preprint. Click to download.

- 20210820ProcessEvaluationAdditionalFile1.docx

- 20210821ProcessEvaluationAdditionalfile2.docx

- 20210821 processevaluationadditionalfile3Codetree.pdf 